\title{
Dil Endüstrisi ve Çevirmenlik Mesleği: Çeviribilim Bölüimü Lisans Öğrencilerine bir Anket Uygulaması
}

\section{Language Industry and the Translation Profession: A Questionnaire for the Undergraduate Students of the Translation Studies Department}

\author{
Ensa Filazi ${ }^{1}$
}

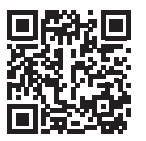

'İstanbul Üniversitesi, Edebiyat Fakültesi, Almanca Mütercim Tercümanlık Anabilim Dalı, Istanbul, Türkiye

\section{ORCID: E.F. 0000-0001-6411-6465}

Sorumlu yazar/Corresponding author: Ensa Filazi (Arş. Gör. Dr.),

İstanbul Üniversitesi, Edebiyat Fakültesi,

Almanca Mütercim Tercümanlık Anabilim Dalı, Istanbul, Türkiye

E-mail: ensa.filazi@istanbul.edu.tr

Başvuru/Submitted: 10.05 .2021

Revizyon talebi/Revision requested:

31.05.2021

Son revizyon/Last revision received:

08.06.2021

Kabul/Accepted: 13.06.2021

Atıf/Citation: Filazi, E. (2021). Dil Endüstrisi ve Çevirmenlik Mesleği: Çeviribilim Bölümü Lisans Öğrencilerine bir Anket Uygulaması. Istanbul Üniversitesi Çeviribilim Dergisi - Istanbul University Journal of Translation Studies, 14, 63-87. https://doi.org/10.26650/iujts.2021.14.0004

Öz

Bilgi edinme noktasında sınırların ortadan kalktığı küresel dünyada, özellikle üniversite okumayı hedefleyen kitlenin tek bir tuşla eğitim içeriklerine yönelik bilgilere ulaşması mümkündür. Bu imkânlar doğrultusunda bütün mesleklere yönelik çalışmalarda bir farkındalık oluşturulmaya çalışılmaktadır. Çevirmenlik mesleğinin geçmiş ve bugünkü konumu karşılaştırıldığında ciddi çalışmalar sayesinde çevirmenliğin farklı bir boyuta ulaştığı ifade edilebilir. Günümüzde çevirmenlik mesleğinin çok geniş iş yelpazesine sahip olduğu, dil endüstrisinin nüfuz ettiği alanlardan hareketle görülmektedir. Dil Endüstrisi; Teknoloji, Dil Eğitimi ve Çeviribilim olmak üzere üç alt başlıktan oluşmaktadır. Adı geçen bileşenlerin işbirliği içinde olması, geniş iş sahalarını ve yeni iş imkânlarını doğurmuştur. Dil endüstrisi faaliyetlerinin kamuoyuna yansımasının çevirmenlik mesleğinin görünürlüğünü artıracağı düşünülmektedir. Dil endüstrisi ve çevirmenlik mesleği ilişkisini irdelemeyi amaçlayan ve anket yoluyla verilerin toplandığı bu çalışmada İstanbul Üniversitesi Çeviribilim Bölümünde okuyan 1. sınıf öğrencilerinin bu bölümü tercih etme sebebi ile 4 yıllık eğitimin sonunda beklentilerinin hangi oranda karşılık bulduğu ve mesleki anlamda farkındalık oluşup oluşmadığı sorularına cevap aranmıştır. Bu doğrultuda hazırlanan anket, 2015 'te ve 2019'da mezuniyet aşamasında olan aynı öğrencilere uygulanmıştır. Anketin sonuçları incelendiğinde mezuniyet aşamasında olan öğrencilerin sözlü ve yazılı çeviri yapma isteğinde ciddi bir düşüşün olduğu görülmektedir. Bu bağlamda dil endüstrisi çerçevesinde çevirmenlik mesleğinin tercih edilen bir mesleğe dönüşebilmesi için çözüm önerilerinde bulunulmuştur.

Anahtar kelimeler: Çevirmenlik Mesleği, Dil Endüstrisi, Farkındalık, Akademik Çeviri Eğitimi, Çeviribilim Bölümü

\section{ABSTRACT}

In the global world, where the boundaries of knowledge have disappeared, it is possible for people aiming to study at a university to access information about their future educational prospects with a single click. This opportunity creates awareness regarding jobs in a specific field of study. When past and present positions of the translation profession are compared, it can be seen that translation has attained a different magnitude thanks to comprehensive 


\begin{abstract}
researches conducted in recent years. Today, the translation profession offers a wide range of jobs and is closely related to areas the language industry has accessed. The language industry comprises three subspecialties: technology, language education, and translation studies. The association between the aforementioned areas has provided wider business arenas, and new business opportunities have arisen out of the connection between them. It was thought that the exposure of language industry activities would increase the visibility of the translation profession to the public. With the help of data collected through a questionnaire, this study aims to examine the relationship between the language industry and the translation profession. Upon ending their four year education, final-year students at the Department of Translation Studies at Istanbul University were questioned about the extent to which their professional awareness had been raised. A questionnaire was supplied to the students who entered the department in 2015 and who then graduated in 2019. When the results of the questionnaire were examined, it was clear there was a significant decrease in the alacrity of the final year, interpretation and translation students. In this context, solutions have been offered to transform the translation profession into a more preferable one within the framework of the language industry.
\end{abstract}

Keywords: Translation profession, language industry, awareness, academic translation education, translation studies department

\title{
EXTENDED ABSTRACT
}

The increase in the number of joint endeavors between the translation industry and the Academy, as well as the inclusion of foreign language courses at universities, have paved the way for the expansion of the language industry in Turkey. Presently, the language industry is comprised of three areas in the international field: translation studies, language technology, and language education. In the 1990s, the concept of the language industry only referred to the processing of language in software; it has since lost its validity in international fields. With the development of various programs for language technology, since the 2000s the scope of the language industry has expanded and all components related to language technology have been included in the industry, making it an important sector. The increase in multilingual studies in the language industry, especially in the European Union, has led to the emergence of new projects and professional areas. In 2009, the European Union General Directorate of Translation (DG Translation) ranked eight sectors within the scope of the language industry: translation, interpreting, software localization, website globalization, tool development for language technology, language training, language-focused consultancy for companies, and the organization of multilingual international conferences. Firms such as IBIS World Industry and CSA Research (Report) regularly conduct research on the language industry. Considering the growth rate in the translation sector, it may be that those who prefer the translation profession have a higher probability for a career in the field. Graduates of foreign language departments are also among the advantaged candidates in the translation industry. However, the extent to which the public recognizes the basic duties of a translation professional should be discussed separately. It has been generally observed from written and visual media-television, the news, the internet, and job advertisements - that the basic responsibilities of translators are not recognized by the public; the professional visibility of translators is regarded less than that of a 
physician or a lawyer. As long as there is a lack of awareness about the duties of the translation profession, other career paths will be chosen. Students who proactively choose to enroll in translation departments can increase their motivation and convey their academic success to their professional life. A person aware of their qualities should be honest with themselves and sincere in their actions. Individuals should recognize their integrity, be aware of their skill set, and know "why, where and how to use these skills" (Şimşek, 2014). In this context, awareness brings about a professional approach to the translation profession. According to Schopp, being a professional means having a sense of responsibility toward one's self, one's client, and the professional situation. It is not enough for the companies that provide translation services to adapt to developments in the translation sector. Also, translation studies departments should be required to convey developments occurring in the profession to candidate translators through their curriculums. In this study, a satisfaction questionnaire was given to the students of the Translation Studies Department of Istanbul University (along with a general assessment) in order to measure their cognizance regarding their intention in choosing this department. In order to examine the students' awareness regarding their choice, especially the first-year students, they were given a questionnaire in 2015. Three years later, a questionnaire of similar questions used in the first questionnaire was given again in the spring semester of the 2018-2019 academic year. Some of the questions in the preliminary questionnaire were also in the final one. Based on the results of the present research, it can be argued that awareness should be raised, regarding the wide range of jobs in the translation profession. However, the Academy is not the only entity capable of facilitating awareness in this matter. The language industry should be more integrated within translation and interpretation departments and cooperationoriented projects and platforms should be developed, especially in Turkey. The Academy is expected to train fully-equipped translators. Although state universities provide extensive theoretical knowledge, they cannot achieve the same success in terms of application. The lack of modern, technological equipment may be one reason for this situation. Translation science, technology, and education - the components of the language industry — should be considered a triad and joint studies should be increased between these fields. 


\section{Giriş}

Dil teknolojisinin gelişmesiyle yabancı dilde profesyonellik beklentisi artmıştır. Yeni teknolojiler geliştikçe daha fazla eğitilmiş iş gücü talep edilmektedir ve söz konusu gelişmeler iş konusunda yeni yaklaşımları ve meslekleri beraberinde getirmektedir (Karakaya, 1997, s. 239). Bu beklentiler doğrultusunda yabancı dile ihtiyaç duyuldukça yabancı dil kurslarının açılması ve üniversitelerde çeşitli yabancı dil bölümlerinin (Mütercim Tercümanlık, Öğretmenlik, Filoloji) kurulması artış göstermiştir. Bu bağlamda dil endüstrisinden bahsetmek mümkündür. Yukarıda söz edilen gelişmelerle birlikte çeviri sektörü ile akademi arasında ortak çalışmaların artması ve Türkiye' deki üniversitelerin bünyesinde yabancı dil kurslarının verilmesi, dil endüstrisinin genişlemesine zemin hazırlamıştır. Uluslararası sahalarda dil endüstrisinin son yıllarda üç alanı kapsadığı görülmektedir: Çeviribilim, Dil Teknolojisi ve Dil Eğitimi. Çeviri bölümleri dikkate alındığında ÖSYM'nin 2020 yılı verilerine göre, Türkiye'de 73 üniversitede toplam 108 Akademik Çeviri Eğitim Programı bulunmaktadır. ${ }^{1} 60$ üniversitede toplam 82 Mütercim Tercümanlık ya da Çeviribilim lisans programı ve bu 60 üniversitenin dokuzunda da ayrıca Uygulamalı Çevirmenlik ön lisans eğitim programı bulunmaktadır. 13 üniversitede de sadece Uygulamalı Çevirmenlik ön lisans eğitimi verilmektedir. Ön lisans düzeyinde toplamda 26 program mevcuttur.

Türkiye'deki üniversitelerde çeviri bölümlerinin artmasıyla Almanca, Arapça, Bulgarca, Çince, Farsça, Fransızca, İngilizce ve Rusça gibi çeşitli dillerde çeviri eğitimi verilmesi; çevirmenlik mesleğinin giderek önem kazandığını ve mesleğe yönelik profesyonel bir bakış açısının geliştiğini göstermektedir. Çevirmenlik mesleğinin dünyada popülerlik kazanması ve birçok çeviri bölümünün açılmasının yanında Türkiye' de akademinin, çeviri derneklerinin ve Mesleki Yeterlilik Kurumunun ortak çalışmalarıyla çevirmenlik mesleğinin resmiyete kavuşması için önemli adımlar atılmıştır. Akademinin ve çeviri sektörünün işbirliğiyle 20122018 yılları arasında Çevirmen Meslek Standardı'nın yayımlanmasından sonra Çevirmen Yeterlilikleri hazırlanmıştır. 2018 yılında İstanbul Üniversitesinin koordinatörlüğünde Mesleki Yeterlilik Kurumuyla bir protokol imzalanmış, toplamda altı alanda çevirmen yeterliliği belirlenmiştir: Yerelleştirme Çevirmeni, Toplum Çevirmeni, Özel Alan Çevirmeni, Işsaret Dili Çevirmeni, Konferans Çevirmeni, Irtibat Çevirmeni. ${ }^{2}$ Gerek üniversite düzeyinde eğitim veren kurum sayısındaki artış, gerekse Çevirmen Meslek Standardı'nın ve Mesleki Yeterliliklerin hazırlanması mesleki gelişim konusunda son derece önemli adımlar olarak değerlendirilebilir. Çevirmenlik mesleğiyle ilgili hâlihazırda yasal bir düzenleme olmamasına karşın Çevirmen Meslek Standardı ve yayımlanacak Çevirmen Yeterlilikleri vasıtasıyla mesleği icra edecek kişilerin taşıması gereken ölçütleri incelemek mümkündür. Bu gelişmeler öğrencilerin çeviri bölümünü tercih etmelerinde teşvik edicidir. Nitekim bir mesleğe yönelik olumlu gelişmeler

1 Erişim adresi: https://www.osym.gov.tr/TR,19226/2020-yuksekogretim-kurumlari-sinavi-yks-kilavuzu.html, 05.12.2020

2 Erişim adresi: https://almancaceviri-edebiyat.istanbul.edu.tr/tr/duyuru/myk-cevirmen-yeterlilikleri-ile-ilgilidegerlendirme-44004F004E0052006E003200580033004E00440063003100, 06.07.2020 
söz konusu olduğunda öğrencilerin ilgili mesleğe karşı motivasyonları da yükselmektedir. Çevirmenlik mesleğinin günümüzde daha iyi konumlandırabilmesi için dil endüstrisinin alana katkısı artırılmalıdır. Kamuoyunu da çevirmenlik mesleğinin konumu ve geniş çalışma alanları konusunda bilinçlendirmek gerekmektedir. Ahmann'a göre çeviri bölümlerinde başarılı olan öğrenciler, başarılarını meslek hayatında da devam ettirmektedir. Bu başarı, öğrencilerin bölümü bilinçli tercih etmelerine bağlanmaktadır. Ayrıca uzun vadede başarılı ürünler ortaya koyan çevirmenler, toplum nezdinde daha fazla saygınlık kazanacak, çeviri ürünlerinin de niteliği artacaktır (Ahmann, 2012, s.36).

Dil endüstrisinin gelişmesiyle çeviri alanında yeni meslekler artmıştır. Bu doğrultuda araştırmada çeviri ve çevirmenlik mesleği ile ilgili çalışmaların artmasının mesleki anlamda önemli bir farkındalık yarattığı düşüncesiyle aday öğrencilerin mütercim tercümanlık ya da çeviri bölümlerini tercih etmelerinde dil endüstrisinin ne derecede etkili olduğu tespit edilmeye çalışılmıştır. Ayrıca Çeviribilim öğrencilerinin 4 yıllık eğitimden beklentilerinin karşılanmasında dil endüstrisinin etkisini ortaya koymak amaçlanmıştır.

\section{Dil Endüstrisi}

Teknolojinin dil eğitimine entegre edilmesi, Türkiye ve dünya ölçeğinde yeni gelişmeleri beraberinde getirmiştir. Dil sorununu çözme adına dile ve türevlerine büyük yatırımlar yapılmaya başlanmıştır ve bu sayede dil endüstrisi önemli bir pazar hâline gelmiştir (Öztürk, 2017, s. 13-14). "Dil endüstrisinin boyutları hakkında net bilgilere sahip olmamakla birlikte, yerelleştirme, bilgisayar ve web tabanlı dil öğrenimi, dil danışmanlığı, dil kaynakları yönetimi ve dil hizmetlerinin ulusal ekonomiler için olduğu kadar şirketlerin yerel, bölgesel ve küresel pazarlardaki başarısı için de ekonomik açıdan giderek artan" bir öneme sahip olduğu vurgulanmaktadır (Kurultay, 2014, s. 116). Dil endüstrisi, sektörler arasında hususi yeri olan bir hizmet sektörüdür. Dil endüstrisi (Language Industry) kavramı, 90`1 yıllarda sadece yazılımlarda dilin işlemesine yönelik bir anlam ifade ederken bu anlam günümüzde uluslararası sahalarda geçerliğini yitirmiştir. 2000 yılından itibaren dil teknolojisine yönelik çeşitli programların gelişmesiyle dil endüstrisinin anlamı da genişlemiş, dil teknolojisini ilgilendiren bütün bileşenler endüstri bünyesine dâhil edilmiş ve dil endüstrisi dönemin önemli sektörlerinden birisi hâline gelmiştir. Bu bağlamda dil endüstrisi Çeviribilim, Dil Teknolojisi ve Dil Eğitimi olmak üzere üç ana başlığı kapsamaktadır. Çeviribilimi sadece makine çevirisiyle sınırlandırmayı doğru bulmayan Budin de dil endüstrisinin çerçevesinin Çeviribilim için heyecanlı, dinamik ve çok katmanlı bir araştırma alanı olduğunu ifade etmektedir. Ayrıca dijital sosyal bilimi, dil endüstrisini ve çok dilliliği “Computational Translation Studies” olarak değerlendirmektedir. ${ }^{3}$ Geçmişte yukarıda adı geçen alanların birbirinden ayrı değerlendirildiği, ancak son dönemlerde ortak bağlantılar sonucunda kesiştikleri görülmektedir (Budin, 2016, s. 187).

3 Çeviribilim alanında yeni gelişen bir araştırma alanı olan 'Bilgisayar Temelli Çeviribilim' çalışmaları farklı bir araştırmaya konu edilebilir. 


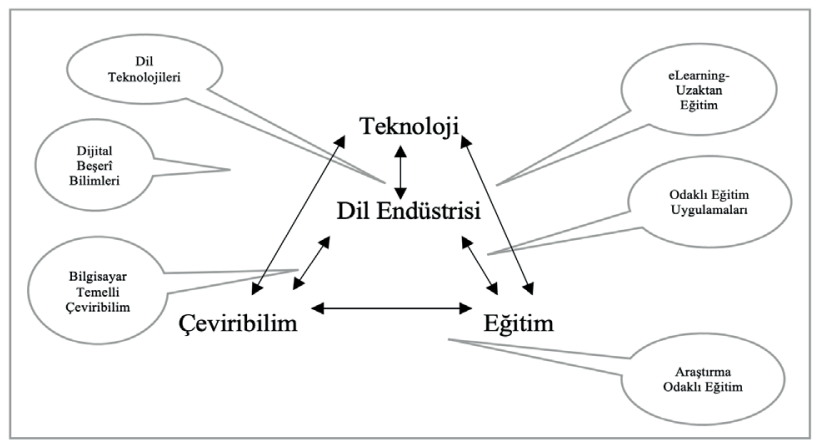

Şekil 1: Dil Endüstrisinin Bileşenleri (Budin, 2016, s. 196)

Budin'in oluşturduğu yukarıdaki şekilden hareketle Çeviribilimin dil endüstrisinin önemli bir paydaşı olduğu ve disiplinlerarası çalışmalara imkân sağladığı ifade edilebilir. Bu şekilde dil endüstrisinin merkezde olduğu; Çeviribilimin, teknolojinin ve eğitimin bir döngü içinde dil endüstrisine katkı sağladığı görülmektedir. Bu bağlamda dil endüstrisinde aktif rol oynayan paydaşların çalışma alanları değerlendirilip söz konusu unsurların uygulanan ankete ne kadar yansıdığı irdelenecektir. Günümüzdeki araştırmalara göre paydaşların Çeviribilime yeni çalışma alanları sağladığı bilinmektedir. Bu doğrultuda dil endüstrisinin akademik çeviri eğitimine katkılarının değerlendirilmesi gerekmektedir. Avrupa Birliği başta olmak üzere Dil endüstrisine yönelik çokdilli çalışmaların artması, yeni projelerin ve mesleklerin ortaya çıkmasını sağlamıştır. Çünkü Avrupa Birliğinin ekonomiyi geliştirme stratejilerden biri de dil teknolojisinin bir araştırma alanına dönüşmesidir. Buradaki amaç, ortak pazarda çok dilliliği sağlamaktır (Budin, 2016, s. 184). Özellikle Avrupa Birliğince benimsenen "Language Industry" terimi, çeviri hizmetini sağlayan (Translation Service Provider) bütün paydaşları kapsamaktadır. Çeviri büroları, serbest çalışan çevirmenler, büyük çeviri şirketleri, çeviri ve dil öğrenim programları üreten firmalar ile yabancı dil eğitim sektörünü içermektedir (Schmitt, Gerstmeyer ve Müller, 2016, s. 33).

2009 yılında Avrupa Birliği Çeviri Genel Direktörlüğü (DG Translation) dil endüstrisi kapsamında sekiz sektör sıralamıştır: Çeviri, sözlü çeviri, yazılım yerelleştirme, web sitesi globalleştirme, dil teknolojisine yönelik araç gelişimi, dil eğitimi, dil odaklı firma danışmanlığı, çok dilli uluslararası konferansların organize edilmesi. Bunun üzerine Direktörlük, 2012 yılında Dil endüstrisinin pazarını araştırmak üzere LIND - Web (Language Industry Platform) platformunu kurmuştur. Bu platformun kurulma amacı, dil endüstrisinin durumunu ve piyasa değerini tespit etmek, dil endüstrisinde aktif rol oynayan kuruluşlar arasında işbirliği ve bilgi alışverişini sağlamaktır. Bu bilgi alışverişinin hedefi, akademik eğitim, dil endüstrisi, meslek kurumları ve AR-GE arasında ortak hareket etme motivasyonunu mümkün kılmaktır (Budin, 2016, s. 184). 
LIND, dil endüstrisinin profesyonel çalışma alanlarını ise şu şekilde sıralamıştır:

- Sözlü Çeviri (Interpreting)

- Altyazı ve Dublaj (Subtitling and Dubbing)

- Yerelleştirme (Localisation)

- Dil Teknolojisi Araçları Geliştirme (Language Technology Tools Development)

- Uluslararası Konferans Organizasyonu (International Conference Organisation)

- Dil Eğitimi (Language Teaching)

- Dil Danışmanlığı (Linguistic Consultancy) ${ }^{4}$

Çeviri sektörüne uzmanlık desteği sağlamaya çalışan LIND, aşağıda belirtilen çalışmalara katkı sunmaktadır: Avrupa Çeviri Forumu (The Translating Europe Forum - TEF), Avrupa Yetkinlik, Beceri ve Meslek Sinıflandirılması (The European Skills, Competences and Occupations Classification - ESCO), Avrupa Çeviri Yüksek Lisans Programı Seçimi (The selection of European Master's in Translation (EMT) Programmes), Avrupa Dil Endüstrisi Araştırması (The European Language Industry Survey). Ayrıca Çeviribilim öğrencilerine araçları ve teknikleri tanıtmak üzere pilot projeler düzenlemektedir. ${ }^{5}$

Dil endüstrisinin önemli aktörlerinden biri olan Alman kuruluşu Transforum, mütercim ve tercümanlık alanlarında öğretim ve uygulama arasındaki koordinasyonu sağlayan bir kuruluştur. BDÜ (Bundesverband der Dolmetscher und Übersetzer e.V - Alman Çevirmenler Birliği) tarafindan kurulan bu kuruluş, 90'lı yıllardan itibaren BDÜ’den ayrılmış, çalışmalarına özerk olarak devam etmiştir. Üye sayılarını kısıtlı tutan Transforum, sonuç odaklı projeler için küçük gruplarla çalışmayı savunmaktadır. Üyelerin çoğu akademisyenlerden oluşmaktadır. Aralarında çeviri dernekleri ve özel sektörden firmalar da bulunmaktadır. Transforum, Türkiye'de Çevirmen Meslek Standardı'nı ve Yeterliliklerini hazırlayan Mesleki Yeterlilikler Eşgüdüm ${ }^{6}$ Grubu'na benzetilebilir. Nitekim adı geçen grup da konsensüs sağlayabilmek için küçük gruplar hâlinde çalışmalarını gerçekleştirmektedir. Transforum'un görevleri şunlardır: öğretim ve uygulama arasında fikir alışverişi sağlayarak, eğitim politikasının gelişimlerini ve reel sektörün beklentilerini tespit etmek; mesleki eğitim ve gelişim üzerine stratejik yönetmelikler/kılavuzlar hazırlayarak mesleğin yararına olan yönetmeliklerin/ kılavuzların hayata geçirilmesine destek olmak, çeviri derneklerinin talep ve önerilerinin yürürlüğe girmesi için katkı sunmak; Mütercim ve Tercümanlık meslek eğitimi ile ilgili gelişmeleri kamuoyuna aktarmak ve Avrupa' daki kurumlarla bağlantıları iyileştirmektir (Transforum, 2020). Transforum, çevirmenlik mesleğine yönelik bir broşür hazırlamıştır. Broşürün asıl amacı, bu mesleği icra etmek isteyenlere bir yol haritası göstermek ve bu alanla ilgilenenlere genel bir bilgi sunmaktır. 2018'de yayımlanan broşürde çevirmenlik mesleğine yönelik belli alanlar sıralanmıştır:

4 Erişim adresi: https://ec.europa.eu/info/departments/translation/language-industry-platform-lind_en\#documents, 14.12.2020

5 Erişim adresi:https://ec.europa.eu/info/departments/translation/language-industry-platform-lind_en, 15.12.2020

6 Standartlar MYK'nin biraraya getirdiği Çalışma Grubu ile Eşgüdüm Grubunun ortak çalışmaları neticesinde belirlenmiştir. 
- Yazılı Çeviri (Übersetzen)

- Sözlü Çeviri (Dolmetschen)

- Yerelleştirme (Lokalisierung)

- İşitsel Görsel Çeviri (Audiovisuelle Translation)

- Terminoloji (Terminologie)

- Dil ve Çeviri Teknolojisi (Sprach - und Übersetzungstechnologie)

- Revizyon (Revizion)

- Proje Yönetimi (Projektmanagement)

- Kültürlerarası Çalışma (Interkulturelles Training) ${ }^{7}$

Yukarıda bahsi geçen kuruluşların Avrupa'daki Akademik Çeviri Eğitimine ve çeviri sektörüne önemli destek verdiği ifade edilebilir. Günümüzde dil endüstrisinin profesyonel çalışma alanlarının sıralanması, akademinin ve çeviri sektörünün geniş bir alana yayıldığının göstergesidir. Budin de AILIA' nın (Association de l'Industrie de la Langue, Language Industry Association - Dil Endüstrisi Derneği) 2015'te yayımladığı dil endüstrisinin çalışma alanlarını daha geniş kapsamda ele alarak üç farklı sektörü ayrıntılı bir şekilde açıklamıştır:

\section{1. Çeviribilim}

\section{a: Çeviri}

i. Uzmanlık alan çevirisinin (Hukuk, İktisat, Sanat, Kültür, Bilim; farklı metin türleri;

uzmanlık metinleri ve bilgilendirici metinler) kısmen artarak otomatikleşmesi ve kapsamlı bir iş akışının parçasına dönüşmesi

ii. Farklı biçimlerde edebiyat, sanat ve medyada çeviri, edebî metinlerin çevirisi, opera, tiyatro, film vb. (bkz. Medya Odaklı Çeviri)

\section{b: Sözlü Çeviri}

i: Konferans Çevirisi (Konferans Çevirmeni)

ii. İkili Görüşme Çevirisi (Toplum Çevirmeni, Kamu Çevirmeni, İrtibat Çevirmeni, Mahkeme Çevirmeni vb.)

\section{c: Medya Odaklı Çeviri}

i: Çok modlu biçimde internette, mobil telekomünikasyonda, sosyal ă̆'da vb.

ii. Senkronizasyon, altyazı, yeniden konuşma (re-speaking), sesli betimleme vb.

iii. Çeviriden ya da tercümeden oluşan karışık klasik türler, yeni metin türleri

iv. kısmen artan bir otomatikleştirme

7 Koordinierung der Praxis und Lehre von Dolmetschen und Übersetzen. Erişim adresi: https://www.transforum. $\mathrm{de} /, 23.12 .2020$ 
d: Yerelleştirme, Globalleşme, Uluslararasılaştırma

i: Yazilım

ii. A $\breve{g}$

iii. Her türden ürün (kullanıcı arayüzü, etkileşim-iletişim )

\section{e: Bilgi Tasarımı}

i. Çokdilli teknik dokümantasyon

\section{f. Terminoloji yönetimi, Sözlükbilim, Dil kaynak yönetimi}

\section{Dil Teknolojileri}

a. Makine çevirisi ve bilgisayar destekli çeviri araçları

b. İçerik Yönetimi (Content - Management)

c. Konuşma dilinin işlenmesi (text - to - speech) (Otomatik dil tanıma ses biyometresi otomatik okuma çıkış1)

d. e-öğrenme şeklinde dil öğrenimi

\section{Dil öğrenimi}

a. Dil eğitimi

b. E-öğrenme yöntemiyle dil eğitimi

c. Dil yeterliliğin test edilmesi (Budin, 2016, s. 195)

Budin'in ayrıntılı bir biçimde listelediği alanlardan hareketle dil endüstrisinde üç ana alanın birbirine bağlı çalıştığı ifade edilebilir. Kapsamlı alan araştırmalarıyla dil endüstrisine gerekli hizmet sağlanmaya çalışılmaktadır. Özellikle bütün alanlarda çeviri faaliyetinin bulunması önemlidir. Bu bağlamda yukarıda Budin'in dil endüstrisi için oluşturduğu alanlar farklı bir bakış açısı olarak değerlendirilebilir:

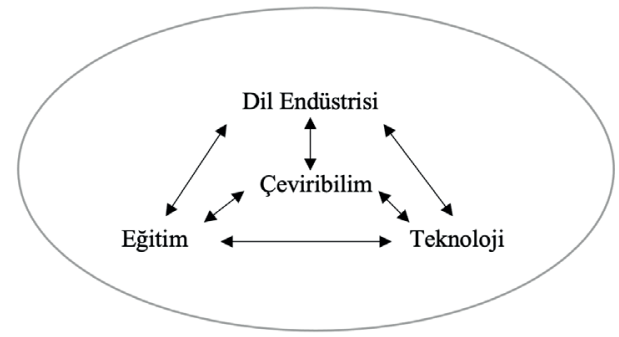

Şekil 2: "Dil Endüstrisi Modeli"» 
Yukarıdaki şekilde Çeviribilimin merkezde konumlandırılması önemlidir. Nitekim çeviri faaliyetiyle dil endüstrisinin büyüme oranı arasında doğru orantılı bir ilişkiden söz etmek mümkündür.

Belli firmalar tarafından yapılan geniş ölçekli anket araştırmaları, dil endüstrisinin paydaşları için önemli bir ihtiyaç analizi ortaya koymaktadır. Dil endüstrisine katkı sağlayan derneklere GALA - Globalization and Localization Association (Küreselleşme ve Yerelleştirme Derneği) örnek gösterilebilir. 2002 yılında kurulan dernek, kendi web sayfasında kâr amacı gütmeyen, küresel dil endüstrisi uzmanları arasında erişim sağlayan ve bu çerçevede faaliyet yürüten kuruluşları bir araya getirmeyi hedefleyen bir platform olduğunu öne sürmektedir. Derneğe dâhil olan kuruluşlar, çeviri bürolarından, dil teknolojisi şirketlerinden, üniversitelerden, danışmanlık hizmeti veren çeşitli global şirketlerden oluşmaktadır. Hedefleri sektörün uzmanları ve işletmecileri arasında işbirliği ve fikir alışverişi sağlamak, dil endüstrisinin büyümesiyle birlikte sektörü başarıya ulaştırmaktır. Başka bir ifadeyle GALA’nın misyonu profesyonel topluluklar oluşturmak, topluluklar arasında bilgi paylaşımında bulunmak, küresel sektörde en iyi uygulamaları geliştirerek üyelerinin başarılı olmasına ve sektörün gelişmesine katkı sunmaktır. GALA'nın web sayfasında Dil endüstrisi ile ilgili bilgiler üç sekmede açıklanmıştır. Dil Hizmeti (Language Service), Dil Teknolojileri (Language Technology) ve Endüstri Kariyerleri (Industry Careers). Dil hizmeti sekmesinde yazılı ve sözlü çeviri ile ilgi açıklamalar bulunmaktadır. Dil Teknolojileri sekmesinde CAT- Araçları (CAT Computer-Aided Translation Tools), Makine Çevirisi (Machine Translation), Çeviri Belleği (Translation Memory), Çeviri Yönetim Sistemi (Translation Management System) ve Uzaktan Eşzamanlı Çeviri Teknolojileri (Remote Simultaneous Interpreting Technologies). Endüstri Kariyerleri (Industry Careers) sekmesinde Mütercim (Translator), Tercüman (Interpreter), Yerelleştirme Proje Yöneticisi (Localization Project Manager), Yerelleştirme Mühendisi (Localization Engineer), Kalite Güvence Uzmanı (Tester / QA Professional), Satış ve Müşteri Yöneticisi (Sales and Account Manager) gibi iş unvanları sıralanmıştır. GALA'nın ayırıcı özelliği, sertifikasyona önem vermesidir. Çeviri ve yerelleştirme sektörünün standartlarının sabit olmadığı ve her zaman yenilenip genişletildiği ifade edilmektedir. Dil endüstrisinin en popüler sertifikalarının ISO (International Organization for Standardization) tarafından verildiği ve ISO 9001: 2015 Kalite Yönetim Sistemleri, ISO 17100: 2015 Çeviri Hizmetleri, ISO 18587: 2017 Makine Çeviri Çıktısı olduğu açıklanmıştır. Bununla birlikte "Dil Endüstrisi Standartları" başlı̆̆ı bulunmaktadır. Burada müşterilere profesyonel bir yaklaşım sağlanabilmesi için çeviri şirketlerinin standartlara bağlı kalmasının önemi vurgulanmaktadır. Bu bağlamda sertifikasyon için hazırlık ve düzenlemeye yönelik destek sağlandığı bildirilmektedir (Gala Global, 2021).

1999 yılında mütercim ve tercümanlar tarafından kurulan "Proz - Dil Uzmanları için Çevrimiçi Topluluk ve İşyeri” kendini dünyanın en büyük çeviri topluluğu olarak tanıtmaktadır. Dünya genelinde bugün 1.170 .500 ' den fazla profesyonel serbest çalışan çevirmen ve çeviri

9 Proz'un üye sayısı günden güne artmaktadır. 
şirketi Proz'a kayıtlıdır. Proz'un misyonu dil endüstrisinde çeviri hizmeti sunanları bir havuzda toplamak ve aralarında fikir alışverişi sağlamaktır. Çevirmenlere hizmet sunan bu sosyal ağda terminoloji çalışmaları, son teknolojik araçlara ulaşma imkânı, eğitimler, uzmanlar arasında işbirliği ya da çeviri projeleri odaklı işbirliği hizmetleri sunulmaktadır. Aynı zamanda bu platform paydaşların hedeflerine ulaşabilmesi için çevirmenlerin kendi deneyimlerini paylaşabilmesine, çalışmalarını geliştirebilmeleri için temel ihtiyaçlarını karşılamasına uygun bir zemin oluşturmaktadır. Proz'da çeşitli yazılımlar üzerinden çevirmenler terminoloji çalışmalarından istifade edebilir ya da mevcut çalışmalara katkı sağlayabilir, ayrıca müşteriler değerlendirilebilir, konferanslar düzenlenebilir ve müşteriyle çevirmen arasında eşleştirmeler yapılabilir. Web sayfalarında Oyun Yerelleştiricisi, Tıbbi (ilaç) Çevirmen, Edebiyat Çevirmeni, Öğrenciler, CPN (Certificate Pro Network) Çevirmenler, Tercümanlar, Proje Yöneticileri, Altyazıcılar, Metin Yazarları (Copywriters), Anadilde Konuşma Partneri (Native Speaker Conversation Partners) ve Mentor (Mentor) şeklinde iş alanları bulunmaktadır (Proz, 2021). Proz da çeviri sektörünün durumunu ölçmek üzere raporlar hazırlamaktadır. 2012'de yayımlanan Çeviri Endüstrisinin Durumuna Yönelik Rapor'u (State of translation industry report) ${ }^{10}$ Schmitt, Gerstmeyer ve Müller değerlendirmiştir. Yazarlara göre bu rapor, serbest çalışan çevirmenlerin gerçek iş hayatını yansıtmaktadır. Hatta yazarlar bu anketin düzenli yapılmasını savunmaktadır. Çevirmenlerden düzenli anket talebinde bulunulmasının çevirmenleri yorabileceğini buna karşın düzenli anket uygulaması yapıldığı sürece çevirmenlik mesleğine yönelik daha verimli karşılaştırmaların yapılabileceğini vurgulamaktadır. Raporun sonuçlarına göre, serbest çalışanların \%60’1 ayrı bir çalışma odası olduğunu bildirmişlerdir. \%40'1 günde 6 - 8 saat ve \%27'si 8 - 10 saat arasında çalıştığını, \%90’ı belli alanlarda uzmanlaştığını beyan etmiştir. Bu sonuçlardan hareketle genel bir kanı olarak kabul gören çeviri alanının geniş tutulması iddiasının çürüdügü ifade edilmektedir. Öte yandan çalışanların \%70'inin son 2 yıl içinde performansının \% 10 arttığı ve \%13'ünün ise performansının \%30'a hatta \%50'ye kadar yükseldiği bildirilmiştir. Bu bağlamda işin rutinleşmesinin, iş tecrübesinin ve teknoloji kullanımının artmasıyla, (örneğin makine çevirisi, çeviri belleği ve dikte yazılım programlarının kullanılması) çalışma performansını olumlu etkilediği ifade edilebilir ${ }^{11}$ (Schmitt ve ark., 2016, s. 41-43).

IBISWorld Industry ve Common Sense Advisory (CSA) gibi firmalar düzenli olarak dil endüstrisine yönelik çalışmalar yapmaktadır. Avrupa'dan sonra dünyanın ikinci büyük çeviri pazarı olan Amerika kökenli bir pazar araştırma firması olarak bilinen IBIS World'ün 2010-2015 yıllarındaki araştırmasına göre tercüme hizmetinin \%54 ve çeviri hizmetinin $\% 41,7$ oranında ciro sağladığı tespit edilmiştir. Ancak bu firmanın araştırma sonuçlarının sadece bir kısmı kamuoyuna yansımaktadır. Örneğin IBIS World'un “Translation Service in the US" adlı raporunun tamamına ulaşabilmek için 925 Dolar bir ücret ödemek gerekmektedir.

10 Erişim adresi: https://www.proz.com/industry-report, üyeler raporun ayrıntısını görebilmektedir, 13.04.2021

11 Söz konusu yıllarda çevirmenin mesaisi günde 8 saat, çalışma hızı ise 2500 - 3000 kelime olarak belirlenmiştir (Schmitt ve ark., 2016). 
"Common Sense Advisory Report" u hazırlayan CSA araştırma firması, dil endüstrisi için en geniş kapsamlı kaynağı sağlamaktadır. 154 ülkede çeviri hizmeti sunan 27.600'e yakın firmaya bir anket uygulamaktadır. Düzenli anket çalışmaları yapan bu Amerikan şirketi, çeviri hizmetine yönelik yeni gelişmeler ve trendler hakkında bilgiler sunmaktadır. Güvenilir veriler sunan CSA raporu, sadece en çok ciro yapan şirketleri sıralamakla kalmayıp üniversite öğrencilerine mesleki yönlendirmeye yönelik danışmanlık hizmeti sunan departmanlara da katkı sağlamaktadır. Ancak bu listelere erişebilmek için yıllık 9.700 Dolar ücret talep edilmektedir. CSA, 2014 yılındaki anketinde çeviri hizmeti alanlarına talebin arttığını vurgulamaktadır. Öte yandan talepler, dil endüstrisindeki gelişmelere göre yıldan yıla değişebilmektedir. CSA, sağladığ 1 verilerle üniversitelerin müfredatlarını yeniden planlamasına yardımcı olmaktadır. Dil hizmeti ve teknoloji alanına yönelik anketin değerlendirilmesi sonucunda Post - Editing, makine çevirisi, video tercümanlığı ve oyun yerelleştirmesi gibi çoğu çalışma alanının üniversite müfredatlarında bulunmadığı ve Çeviribilim bölümlerinin dil endüstrisi pazarıyla aynı doğrultuda hareket etmesi gerektiği vurgulanmaktadır.

Genel anlamda profesyonel bir çevirmenden bir ya da birkaç alanda uzmanlaşması beklenmektedir. Hukuk, iktisat, makine mühendisliği gibi çeşitli teknik alanlarda deneyim kazanılması ve art alan bilgisine sahip olunması gerekmektedir. Lakin 90'a yakın mühendislik alanının olduğu düşünülürse, çevirmenin teknik bir çevirmen olarak uzmanlaşabilmesi imkân dâhilinde görülmemektedir. Bu bağlamda CIUTI'nin (Conférence Internationale Permanente d'Instituts Universitaires de Traducteurs et Interprètes - Üniversite Düzeyinde Eğitim Sunan Kurumların Uluslararası Daimi Konferansı) uyguladığı bir ankette "Eğitim sürecinde hangi tamamlayıcı dersi seçtiniz?" (Which, if any, complementary subjects did you choose within your studies?), sorusuna öğrencilerin \%45'inin "None" "hiçbiri”" cevabını vermesi dikkate değerdir (Schmitt ve ark., 2016, ss. 43-56).

Dil endüstrisine katkı sağlayan araştırmalar yukarıdaki çalışmalarla sınırlı değildir. Avrupa Dil Endüstrisi Derneği de (elia.: European Language Industry Association) endüstrisinin gelişmesi, sektörlerin bir araya gelebilmesi için farklı ülkelerde düzenli olarak etkinlikler organize etmektedir. Kâr amacı gütmeyen bu dernek, bir ticari birliği temsil etmektedir. Dernek, Avrupa Birliğine üye ve aday ülkeler arasında ticari işbirliği sağlayabilmek için kurulmuştur. Hedefi, sektörler arasında bilgi, deneyim ve uzmanlık alışverişini sağlamaktır. 2010 yılında İstanbul' da düzenlenen “Elia Istanbul Network Days” adlı toplantıya 27 ülkeden 70'in üzerinde şirket katılmıştır (Özkaya, 2010). Bununla birlikte dil endüstrisinde aktif rol oynayan çeşitli uluslararası web platformları da bulunmaktadır.

Yukarıda bahsi geçen gelişmelerin Türkiye'deki çeviri bölümlerinin müfredatlarına ne oranda yansıdığı incelenmelidir. Aslında LIND' in ve Transforum'un çalışmaları incelendiğinde destek verdikleri alanların çoğunun müfredatta yer aldığı ancak bazı derslerin bölümler tarafından açılmadığı görülmektedir. Bu noktada Almanca Mütercim Tercümanlık Anabilim Dalı müfredatındaki “Altyazı” ile "Görsel İşitsel Çeviri” dersi örnek gösterilebilir. Bu durumun sebeplerinden biri, alanda az sayıda öğretim elemanının bulunması, diğeri de çeviri sektöründen 
akademiye kısmi zamanlı öğretim elemanı transferinin gerçekleştirilmemesidir. Öte yandan teknolojinin ilerlemesine koşut olarak Çeviribilim alanı da kendini sürekli güncellemelidir. Bu bağlamda özellikle devlet üniversitelerine bağlı çeviri bölümlerine teknolojik donanım sağlanmalı ve bu amaçla devlet bütçesinden ve dil endüstrisi bileşenlerinden destek alınmalıdır.

Çeviri sektöründeki büyüme oranına bakılırsa çevirmenlik mesleğini tercih edenlerin kariyer şansının yüksek olduğu düşünülebilir. Sadece Çeviribilim bölümü mezunları değil, ayrıca yabancı dil bölümlerini tercih edenler de çeviri sektöründe avantajlı adaylar arasındadır. Ancak çevirmenlik mesleğinin temel görevlerinin toplum nezdinde ne kadar bilindiği ayrıca tartışılmalıdır. Çünkü genel anlamda çevirmenin temel görevlerinin toplum tarafından bilinmediğini, yazılı ve görsel medyadan, daha doğrusu televizyondan, haberlerden, internetten ve iş ilanlarından gözlemlemek mümkündür. Çevirmenliğin mesleki görünürlüğünün, bir hekimin ya da bir avukatın görünürlüğü kadar olmadığı bilinmektedir. Çevirmenlik mesleğinin çalışma alanlarına yönelik bir farkındalık oluştuğu sürece doğru bir mesleki seçim de sağlanacaktır. Tıp eğitimine talip olan bir öğrencinin anatomi ya da sağlık bilgisi içeren bir müfredattan sorumlu olacağını bilmesi gibi Çeviribilim bölümünü tercih edenler de bölümünün bileşenleriyle ilgili daha net bilgilere ulaşmalıdır (Ahmann, 2011, s. 34).

\section{Ahmann, "Das Trügerische am Berufsbild des Übersetzers” kitabında „Yeni Başlayan} Öğrencilerin Beklentileri - Ampirik bir Araştırma”" (Erwartungen von Studienanfängern eine Fallstudie) adlı bir ankete yer vermiştir. Bu anket, mütercim ve tercümanlık mesleğinin kamuoyundaki değerini ve toplumun dil uzmanlığı mesleğine (Sprachmittler) karşı hangi bilgi ve tutum düzeyinde olduğunu saptamak açısından dikkate değerdir. Bu bağlamda öğrencilerin, hangi görüş, düşünce ve beklentiyle FASK’taki (Fachbereich Translation, Sprach- und Kulturwissenschaft in Germesheim) Mütercim Tercümanlık bölümünü tercih ettikleri tespit edilmeye çalışılmıştır. Meslek seçimine yönelik olan anket, FASK Üniversitesinde 2007/2008 eğitim yılı güz döneminde "Dil, Kültür ve Çeviri” bölümü (Sprache Kultur, Translation BA) ile çeviri dersi alan altı farklı bölümdeki öğrencilere uygulanmıştır. ${ }^{12}$ Anket sonuçlarına göre çeviri bölümünü okumaya karar veren öğrenciler, genelde dille ilgili (etwas mit Sprache) bir bölüm seçtiklerini düşünmektedir. Örneğin öğrencilerin \%93'ü, çeviri eğitiminde dilsel ve kültürel yeterliliğe sahip olmaları gerektiğini düşünmektedir. Ancak bu alanın eğitiminin sadece dil bilgisinin düzeltilmesi ve kültürel birikimin sağlanması ile sınırlandırılması doğru değildir. Ana dili ile yabancı dil edincinin geliştirilmesiyle birlikte öğrencilerin elektronik veri, proje yönetimi, kalite güvencesi, terminoloji yönetimi, Çeviri Belleği Sistemi (Translation Memory System), muhasebe ve faturalandırma gibi alanlarda da kendisini geliştirmesi gerekmektedir (Ahmann, 2012). Çevirmen Meslek Standardı'nda yukarıdaki kriterler temel yeterlilikler olarak yer almaktadır. Bu bağlamda söz konusu ölçütlerin Mütercim Tercümanlık bölümlerinin müfredatına dâhil edilmesi önem arz etmektedir. Anket sonuçlarına göre öğrencilerin \%21’i Çeviribilim

12 İngiliz Dili ve Edebiyatı, Amerikan Dili ve Edebiyatı ve Anglofon Edebiyatından birer çeviri dersi ve Romantistik Bölümünden üç çeviri dersi (Ahmann, 2012) 
bölümünü edebiyat çevirmeni olma idealiyle tercih etmektedir. Ancak Çeviribilim (Bölümü) müfredatının geniş yelpazesi göz önüne alındığında sadece edebî metinlerle değil uzmanlık bilgisi gerektiren kullanma kılavuzu, makine ve otomotiv alanına yönelik teknik metinlerle de karşılaşılmaktadır. Bu durum da öğrencilerin motivasyonunu düşürmektedir. Bununla birlikte öğrencilerin \%3’ü teknolojik okuryazarlık becerilerinin önemli olmadığını düşünmektedir. Lakin Çeviribilim alanında teknoloji göz ardı edilemez. Bir mesleğin profilinin incelenmesi bölüm seçiminde önemlidir. Örneğin çevirmenlik mesleğini icra etmek isteyenlerin hem serbest hem de daimi eleman olarak çalışabildiklerinin farkında olması gerekmektedir. Öncelikle serbest çalışan; özgüven, kişisel inisiyatif, takım ruhu (kurumsal ruh) gibi özelliklere sahip olmalıdır. Bununla birlikte çevirmenlik mesleğinde sabit iş saatleri olmayabilir; gerektiğinde çevirmen mesainin dışına çıkıp çalışmalarını tamamlamak zorunda kalabilir. Bu bağlamda çevirmen adayı daimi veya sabit çalışmak istediğinde, söz konusu koşulları göz önünde bulundurmak zorundadır. Titizlik, çalışkanlık, organizasyon yeteneği, açıklık, sabırlılık, spontan olma, disiplinlilik, dikkatlilik, itina, özgüven gibi özelliklerin çevirmenlik mesleğinde önemli olmasına rağmen öğrenciler tarafından pek dikkate alınmadığı tespit edilmiştir (Ahmann, 2012, s. 34-57).

Yukarıda dil endüstrisi kapsamında sıralanan çeviri faaliyetleri dikkate alındığında, sosyal etkileşim, takım çalışması, süreç odaklı çalışma gibi kriterlerin çevirmenlik mesleğinden beklendiği görülmektedir. Bu itibarla çevirmenlik mesleğini icra etmek isteyenlerin bir proje yöneticisi gibi düşünülmesi gerektiği vurgulanmaktadır. Proje yönetiminde olduğu gibi çevirmenler teknik redaktör, ürün geliştiricisi, pazarlama uzmanı, grafiker, web tasarımcısı, müşteri hizmetleri personeli, kullanabilirlik test hizmeti uzmanı ve müşteri ile iletişim becerilerini sağlamalıdır. Çünkü bir çeviri projesi yönetilirken sadece metnin çevirisi değil, insan ilişkilerinin de iyi yönetilmesi gerekmektedir (Risku, 2009, s. 136).

Mascha Dabić “Übersetzen und Dolmetschen Rollenbilder, Arbeitsfelder, Implikationen für den Unterricht" adlı çalışmasında kendi öğretim sürecinde çevirmenlik mesleği ilgili öğrencilere yönelttiği mütercimlik ya da tercümanlık mesleği hangi motivasyonlarla tercih edilmektedir? Uzmanlı alan ĕgitimi veren üniversitelerden beklentiler nelerdir? Çevirmen adaylarının üniversite eğitiminden sonra iş hayatından beklentileri nelerdir? sorularının cevaplarını aramıştır. Öğrencilerin çevirmenlik mesleği ile ilgili farklı fikirleri bulunmaktadır. Bazı öğrenciler sadece sözlü, bazıları da yazılı çeviri yapmak istediklerini ifade etmiştir. Öğrencilere göre bunun sebebi yazılı çeviride sakin bir ortamın bulunması, sözlü çeviride ise görünürlük isteğinin uyanmasıdır. Bunun dışında özellikle rutinlik sağlayacağı düşüncesiyle hukuk, iktisat ya da tıp gibi uzmanlık alanlarından sadece birine odaklanma isteği bulunmaktadır. Öğrencilerin çok az bir kısmı, hem sözlü hem de yazılı çeviri yapmak istediklerini bildirmişlerdir. Ancak gerçek hayatta çok az kişi mesleki anlamda tek bir alana yönelebilmektedir. Nitekim çeviri hizmetiyle geçim sağlandığında durum farklılaşmaktadır. Çok az çevirmen sadece arzu ettiği tek bir alanda çalışabilmektedir. Çevirmenlik mesleğinden her daim esneklik ve öğrenime açıklık beklenilmektedir. Çevirmenler iş alanlarında çeşitli rollerde hizmet verebilmektedir. 
Meslek icra edilirken, toplumda tanınma, iş çevresi oluşturma ve aynı anda birkaç işi yürütebilme gibi (mobilite) hususlar mesleki memnuniyeti sağlamaktadır ve mesleğe karşı bir farkındalık yaratmaktadır. Bu bağlamda üniversite çerçevesinde öncelikle öğrencilerin, yetenek, karakteristik nitelik, ekonomik hırs, ilgi alanı gibi özellikleri belirlenmeli, çeşitli alanlarda çekinmeden çalışmaları ve farklı görevleri deneyimlemeleri sağlanmalıdır. Üniversiteler, çeşitli çalışma alanlarını simüle etmek için meslek odaklı bir çerçeve sunmalı ve bireyin çalışma deneyimini yerine getirmesi için uygun ortamlar hazırlamalıdır (Dabić, 2018, s. 212).

Bu araştırmanın yapıldığı dönemde (2016) Hacettepe Üniversitesi Fransızca Mütercim Tercümanlık Bölümü öğrencilerine cinsiyet, lise türü, yurtdışında eğitim alma durumu, sınıf kademesi, aylık gelir durumu ve bölümü tercih etme nedeni gibi değişkenlerin bölüme yönelik tutuma etkisini ortaya koymayı amaçlayan bir anket çalışması yapılmıştır. Çalışmada 1. sınıfta okuyan öğrencilerin 2., 3. ve 4. sinıfta okuyan öğrencilere göre daha olumlu bir tutuma sahip olduğu tespit edilmiştir. Bu sonucun öğrencilerin üniversiteyi kazandıklarında heyecanlı olmalarından ve "derslerin çoğunlukla mesleğe giriş derslerinden oluşması" ndan kaynaklandığ 1 ifade edilmiştir. 2., 3. ve 4. sınıfta okuyan öğrencilerin uzmanlık derslerinde zorlanmalarından ve mezuniyet aşamasında iş kaygısı yaşamalarından dolayı bölüme karşı olumsuz bir tutum sergiledikleri belirtilmiştir. Öğrencilerin kararsız tutumunun olumlu tutuma dönüştürülmesi ve 1. sınıfta sahip oldukları olumlu tutumları mezuniyete kadar korumaları gerektiği ifade edilmiştir. Bölüm mezunlarının lisans öğrencileriyle iş tecrübelerini paylaşmalarına imkân verilmesi, bölüme farklı alanlardan uzman kişilerin davet edilmesi önerilerinde bulunulmuştur (Tokalak Baltacı, 2016). Bu bağlamda 2010 yılında kurulan Türkiye Çeviri Öğrencileri Birliği (TÜÇEB) önemli bir rol üstlenmektedir. Çeşitli üniversitelerin çeviri bölümü öğrencileri tarafından kurulan bu birlik, reel sektör ile akademi arasında bir köprü işlevi görmektedir. Başka bir deyişle Çeviribilim ve mütercim tercümanlık öğrencilerinin sesi olan TÜÇEB, dönem dönem etkinlikler düzenleyerek çevirmenlik mesleği ile ilgili sorunları ve gelişmeleri duyurmaya çalışmaktadır. ${ }^{13}$ Bu birliğin faaliyetleri Tokalak Baltacı'nın (2016) yaptığı öneriler çerçevesinde dikkate alınabilir.

Yukarıda bahsi geçen çalışmalardan hareketle öğrencilerin çeviri bölümünü bilinçli seçtiği sürece motivasyonlarını artırabileceği ve okuldaki başarısını meslek hayatına yansıtabileceği çıkarımında bulunmak mümkündür. Bunun için sadece çeviri hizmeti sağlayan firmaların çeviri sektöründeki gelişmelere uyum sağlamaları yeterli değildir. Ayrıca Çeviribilim bölümlerinin de meslekteki hızlı gelişmeleri çevirmen adaylarına müfredat aracılığıyla aktarması gerekmektedir (Ahmann, 2012, s. 39-62).

13 Erişim adresi: https://www.facebook.com/TurkiyeCeviriOgrencileriBirligi/about/?ref=page_internal, 13.04.2021 


\section{3. Çeviribilim Bölümlerinde Farkındalık}

Farkındalık, son yıllarda çoğu disiplinde yaygınlık kazanan bir kavramdır. İngilizcede mindfulness, awareness ${ }^{14}$ ve Almancada Achtsamkeit, Bewußtsein ${ }^{15}$ olarak kullanılan farkındalık kavramı, Türk Dil Kurumunun güncel sözlük web sayfasında "farkında olma durumu" şeklinde açıklanmaktadır. ${ }^{16}$ Bilinçli - farkındalık olarak da açıklanan farkındalığın en yaygın tanımı dikkatlilik ve idrak edilen zamandaki olayların farkında olma hâlidir (Brown ve Ryan, 2003 aktaran Özyeşil, 2011, s. 45). Farkındalık kavramı bilinç ile ilişkilendirilmekte ve genellikle psikolojik anlamda gelişmiş, olgunlaşmış insan tipiyle özdeşleştirilmektedir (Hisli Şahin ve Yeniçeri 2015, s. 49). Şimşek, farkındalığı "insanın kendini, kendi özelliklerini iyi tanıması, kendi yeteneklerinin farkında olması; rahatlık, mutluluk, huzur ve başarı sınırlarının nerede olduğunu bilmesi” şeklinde tanımlar. Kendi niteliklerinin farkında olan bir insan, öncelikle kendisine karşı dürüst ve eylemlerinde samimi olmalıdır. Birey, bir içsel bütünlük sağlaması gerektiğini bilmeli, kendi yetilerinin farkında olmalı ve yetilerini "niçin, nerede ve nasıl kullanacağıı”" nın bilincinde olmalıdır (Şimşek, 2014). Bu bağlamda farkındalık kavramının çevirmenlik mesleğinde profesyonel bir yaklaşım beklentisi doğurduğu söylenebilir. Schopp’a göre profesyonel olmak, öncelikle kendisine, müşterisine ve mesleki durumuna karşı bir sorumluluk bilincine (verantwortungsvoll) sahip olmaktır. Profesyonellik, sinırlarının bilincinde olma, bilgi ve becerilerinin farkında olarak kişisel yeterlilik ve kalifikasyona ulaşma ve görevlerini mesleki alanda (Berufsfeld) uygun bir şekilde icra etmektir. Gerçek profesyonellikte kolektif bir öz davranışın/tutumun (kollektive Autonomie) ötesinde geliştirilmiş bir uzmanlık bilgisi (Know-How) talep edilmektedir. Bundan dolayı çevirmenlik mesleğini tam zamanlı icra edenlerin, kendilerini sadece bir dil aktarıcısı olarak değil (Sprachmittler), daha çok kültürlerarası ve kültür ötesi iletişim aracı üreten uzman olarak görmesi gerekmektedir (Schopp F. Jürgen, 2012, s. 328). ${ }^{17}$ Ahmann'ın belirttiği üzere öğrenciler çevirmenlik mesleği ile ilgili bir bilinç oluşturduğu sürece mesleki başarıya ulaşacaktır. Bu bakış açısı da meslekteki profesyonelleşmenin ilk adımı olarak düşünülebilir (Ahmann, 2012). Mütercim Tercümanlık bölümlerinin web sayfaları incelendiğinde de çevirmen adaylarına eğitim boyunca bir farkındalık kazandırılmaya çalışıldığı görülmektedir. Bu durum aşağıda birkaç örnekle özetlenmiştir: İstanbul Üniversitesi Almanca Mütercim Tercümanlık Anabilim Dalı kendini “.... gerek bütün dünyada gerekse Türkiye'de genç, ama o oranda da iki farklı dilde sonsuz bir kültürel birikim, farkindalık gerektiren bir bilim dalı" şeklinde tanıtmıştır. ${ }^{18}$ Marmara Üniversitesi Mütercim

14 Erişim adresi: https://tureng.com/tr/turkce-ingilizce, 06.04.2021

15 Erişim adresi: https://www.dict.cc/, 06.04.2021

16 Türk Dil Kurumu Sözlükler. Erişim adresi: https://sozluk.gov.tr/, 06.04.2021

17 Erişim adresi: https://www.yumpu.com/de/document/read/15134298/sprachberufe-in-bewegung-bemerkungenzum-begriff-der-vakki, 29.10.2020

18 İstanbul Üniversitesi, Almanca Mütercim Tercümanlık. Erişim adresi: https://almancaceviri-edebiyat.istanbul. edu.tr/tr/content/anabilim-dalimiz/tarihce, 29.10.2020 
Tercümanlık Bölümü “çeviriyle ilgili tüm alanlarda farkındalık”19 kazanmış; Yıldız Teknik Üniversitesi Fransızca Mütercim ve Tercümanlık Bölümü “... sektörde yeniliklere uyum sağlayabilen, meslekleşme konusunda farkındalığ $l$ yüksek, çok yönlü” ${ }^{20}$ çevirmenler yetiştirmeyi hedeflemektedir. Yaşar Üniversitesi Mütercim Tercümanlık Bölümü “farklı kültürlerin dil ve kültür katmanlarına ilişkin farkındalık" ${ }^{21}$ kazanmış ..."; Çankaya Üniversitesi Mütercim Tercümanlık (İngilizce) Bölümü farkındalıklarl "22 artmış; İzmir Ekonomi Üniversitesi İngilizce Mütercim Tercümanlık Bölümü, “... dil farkındalı̆̆ına sahip yazılı ve sözlü çevirmenler” yetiştirmeyi hedeflediklerini açıklamaktadır. Yine İstanbul Üniversitesi Fransızca Mütercim Tercümanlık Anabilim Dalı "kendine ve topluma olan sorumluluklarının farkında bireyler" yetiştirmeyi amaçlamaktadır. ${ }^{23}$ Yukarıdaki örneklerden hareketle, akademik çeviri eğitiminin hedefi öğrencilere Türkiye'deki ve dünyadaki çeviri alanlarını tanıtmak ve öğrencileri farkındalık kazanmış bireyler olarak çevirmenlik mesleğine hazırlamaktır. Öğrencilerin belli bir farkındalıkla mesleğe yönelmeleri önemlidir. İstikrarlı bir karar ile yapılan bölüm tercihleri, öğrencinin akademik başarı düzeyini artıracaktır.

\section{Anket Analizi ve Değerlendirme}

Bu çalışmada öğrencilerin bölüm seçimiyle ilgili farkındalıklarını ölçebilmek için İstanbul Üniversitesi Çeviribilim Bölümü öğrencilerine genel bir değerlendirme doğrultusunda bir memnuniyet anketi uygulanmıştır. 2015 yılında uygulanan ön ankette 14 ve 2019 yılında uygulanan son ankette ise 11 çoktan seçmeli soru bulunmaktadır. 2015-2016 öğretim yılı güz döneminde İstanbul Üniversitesi Çeviribilim Bölümünün 1. sınıfının temel dersini oluşturan 'Çeviri Amaçlı Metin Çözümlemesi I (ÇAMÇ I)' dersi üç anabilim dalının ortak katılımıyla (Almanca Mütercim Tercümanlık (AMT), Fransızca Mütercim Tercümanlık (FMT), İngilizce Mütercim Tercümanlık (IMT)) işlenmektedir. Katılımın yüksek olmasından dolayı bu ders, anket çalışmasının örneklemi olarak tercih edilmiştir. Anket, yeterli çoğunluğu sağlamak üzere ÇAMÇ vize sınavının bitiminde uygulanmıştır. Öğrencilerin bölüm seçimine yönelik farkındalıklarını incelemek amacıyla özellikle 1. sınıf öğrencilerinin anketi dikkate alınmıştır. 3 yıl sonra, 20182019 öğretim yılı bahar döneminde aynı örneklem grubuna benzer sorulardan oluşan bir anket yeniden uygulanmıştır. Ön ankette yöneltilen soruların bir kısmı son ankette de kullanılmıştır. Son anket çoğunluğu sağlamak için üç ana bilim dalında ortak işlenen 'Günümüzde Çeviri ve Çevirmenlik (GÇÇ)’ dersinin final sınavının bitiminde uygulanmıştır. İkinci anketin amacı,

19 Marmara Üniversitesi, Mütercim - Tercümanlık, Tarihçe ve Program Tanıtımı. Erişim adresi:http://imt.mt.fef. marmara.edu.tr/genel-bilgiler/tarihce-ve-program-tanitimi , 29.10.2020

20 Yıldız Teknik Üniversitesi. Erişim adresi: http://www.bde.yildiz.edu.tr/bde/1/Hakk\%C4\%B1nda/17, 29.10.2020

21 Yaşar Üniversitesi, Mütercim- Tercümanlık Bölümü. Erişim adresi: https://dti.yasar.edu.tr/mutercim-tercumanlikbolumu/, 29.10.2020

22 Çankaya Üniversitesi, Mütercim - Tercümanlık (İngilizce) Bölümü. Erişim adresi: https://mtb.cankaya.edu.tr/ ogrencilerimizle/, 29.10.2020

23 İstanbul Üniversitesi, Fransızca Mütercim Tercümanlık. Erişim adresi: https://almancaceviri-edebiyat.istanbul. edu.tr/tr/content/anabilim-dalimiz/tarihce, 29.10.2020 
öğrencilerin 4 yıllık eğitimin sonunda bölüm seçimine yönelik beklentilerinin karşılanıp karşılanmadığını tespit etmek ve 2015 yılında meslekle ilgili düşüncelerine 4 yılın sonunda ne kadar bağlı kaldıklarını öğrenmektir. Bu bağlamda öğrencilerin bölümden beklentileri (1. Sınıf) ve memnuniyet düzeyleri (4. Sınıf) arasındaki ilişki karşılaştırılmış, özellikle çevirmenlik mesleği ile ilgili farkındalıklarının ne kadar arttığı ölçülmüştür. Resmî verilere göre 20152016 güz döneminde ÇAMÇ dersine AMT'den 82, FMT'den 81 ve İMT'den 69 öğrenci kayıtlıdır. Kayıtlı olan 232 öğrenciden 198'i, ÇAMÇ’ın vize sınavına katılmıştır. 11 anket eksik doldurulduğu için değerlendirmeye alınmamıştır. AMT'de 28, FMT'de 31, İMT'de 45 olmak üzere toplamda 104 öğrencinin anketi değerlendirilmiştir. 2018-2019 bahar döneminde GÇÇ dersine AMT'den 37, FMT'den 23 ve İMT'den 56 olmak üzere toplam 116 öğrenci kayıtlıdır. AMT'den 27, FMT'den 14 ve İMT'den 44 olmak üzere toplamda 92 öğrenci anketi yanıtlamıştır. 7 anket boş olarak teslim edildiğinden toplamda 85 anket değerlendirilmiştir.

Anketin verileri "Eğitimde Değerlendirme X49 Excel"24 programıyla analiz edilmiştir. 2015 ve 2019 yıllarında uygulanan anketlerin sonuçları karşılaştırılıp diyagramlarla gösterilmiştir. Aşağıdaki diyagramlarda ankete katılan öğrencilerle ilgi sayısal veriler dikkate sunulmuştur.

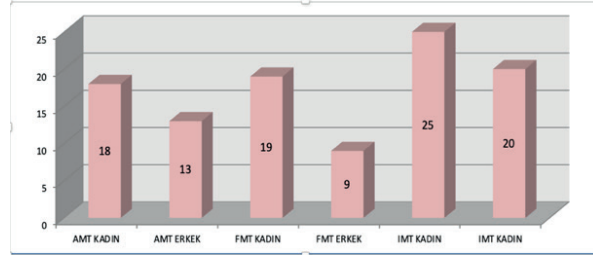

Diyagram 1: (2015) Katılan Öğrenci Sayıs1

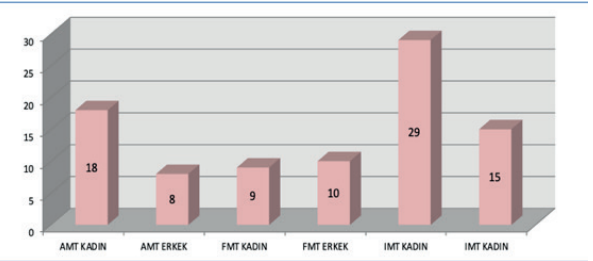

Diyagram 2: (2019) Katılan Öğrenci Sayıs1

Diyagram 1 (2015) ve Diyagram 2 (2019)'ye göre “Mütercim ve Tercümanlık” bölümünü çoğunlukla kadınlar tercih etmektedir. ${ }^{25}$ Ancak 2015 ve 2019'da kadın ve erkek katılımının oranında büyük bir fark olmadığından anket sonuçlarında cinsiyet değişkeni dikkate alınmamıştır.

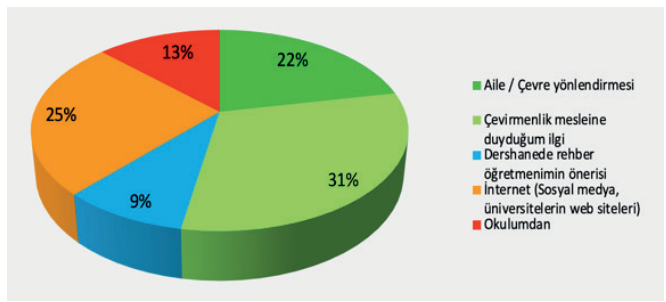

Diyagram 3: (2015)

24 Erişim adresi: https://www.egitimhane.com/idareciler-icin-dosya-ve-dokumanlar-db2.html, 12.03.2021

25 Erişim adresi: https://yokatlas.yok.gov.tr/lisans.php?y=105690657, 12.03.2021 
Bu bölümde 2015 ve 2019 anketlerinin sonuçları karşılaştırılmadan önce 2015'te öğrencilerin bölümle ilgili bilgileri nasıl edindikleri öğrenilmeye çalışılmıştır.

Diyagram 3'e göre 2015 'te öğrencilerin \%31'i bölümü “çevirmenlik mesleğine duyulan ilgi" den dolayı seçtiklerini bildirmişlerdir. \%25'i de sosyal medyadan bilgi edindiğini belirtmektedir. Bu orandan hareketle çevirmenlik mesleğinin sosyal medyaya yeterince yansımadığı, öte yandan bölüm tercihinde aile ve çevrenin yönlendirmesinin son derece etkili olduğu söylenebilir.

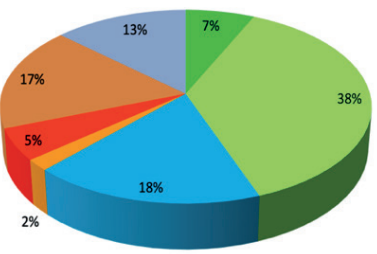

Diyagram 4: (2015)

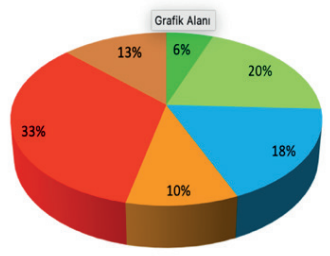

"Bravo, Türkive bir centrendahatanc. " çok güzel bir seçimmiș. " ç̧ok güzel, kendi i̧̧ini colection " Ankę:ke öretmenili

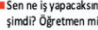

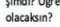

Diyagram 5: (2019)

Diyagram 4'e göre öğrencilerin \%38'i, çevresinden “çok doğru bir tercih yapmışsın ve iş alanı çok geniş" biçiminde bir tepki almıştır. Bu sonuca göre mesleğe karşı ilginin arttığ ve sosyal çevre desteğinin mesleki açıdan önemli olduğu ifade edilebilir. Ancak 2019 yılının sonuçlarını gösteren Diyagram 5'te “Çok güzel bir seçimmiş. Hayırlı olsun” ifadesinin \%20 'ye gerilemesi söz konusudur. "Keşke öğretmenlik bölümü kazanabilseydin” ifadesi \%5 iken, 2019'daki 'Sen ne iş yapacaksın şimdi? Öğretmen mi olacaksın?" ifadesinin \%2'den \%33'e yükselmesi de dikkate değerdir. "Çok güzel, kendi işini yapabileceksin" ifadelerinin oranında (\%18) bir değişiklik olmaması olumlu bir sonuç olarak değerlendirilebilir. Dil endüstrisinin geniş çeviri faaliyetleri göz önüne alındığında öğrencilerin bilinçli seçiminden ziyade, kamuoyunun ciddi bir bilinçlenme ihtiyacının olduğu söylenebilir.
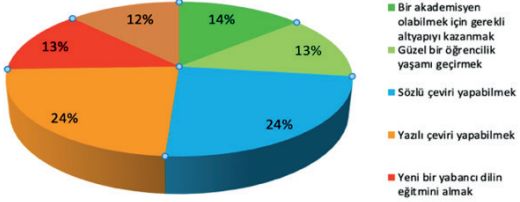

Diyagram 6: (2015)

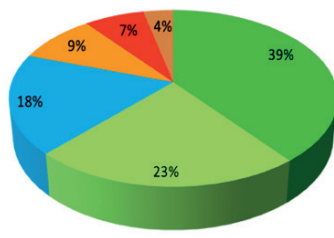

istigyorum. Devam

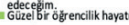

yaşadim.

II Söllü çeviri yapmak

istiyordum, yapacağm - Yaall çeviri yapmak Sadece diplomam olsun Sadece diplomam
dive duşuñoüm.

Diyagram 7: (2019)

Diyagram 6' da 2015 y1lında “'Bu bölümde almakta olduğunuz eğitimden temel beklentiniz nelerdir?" ve Diyagram 7'de 2019'da katılımcılara yöneltilen “Bu bölümde aldığınız eğitim temel beklentinizi karşıladı mı?” sorularının cevapları karşılaştırılmıştır. Diyagram 6'da 
“sözlü çeviri yapabilmek” ifadesi \%24 iken, Diyagram 7'de \%18'e düşmüştür. "yazılı çeviri yapabilmek” ifadesinde ise \%24'ten \%9'a ciddi bir düşüşün olduğu görülmektedir. Diyagram 7'de (2019) "Araştırmacı olmak istiyorum. Devam edeceğim” cevabının oranı \%39‘a yükselmiştir. Mevcut sonuç bu alanda bilimsel çalışma yapma arzusunun öğrencilerde oluşması bağlamında olumlu bir gelişme olarak değerlendirebilir.

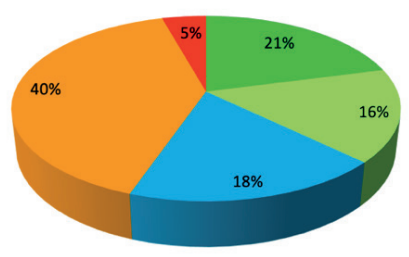

Diyagram 8: (2015)

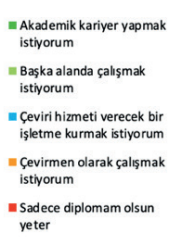

yeter

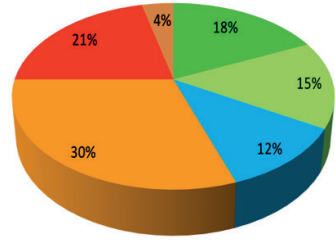

Diyagram 9: (2019)

Diyagram 8'de 2015 yılında “Bu bölümden mezun olduğunuzda aşağıdakilerden hangisini veya hangilerini yapmak istiyorsunuz?" sorusunun cevapları; 2019 sonuçlarını gösteren Diyagram 9'daki “Bu bölümden mezun olduğunuzda hangi alana yönelmeye karar verdiniz" sorusunun cevapları ile karşılaştırılmıştır. Diyagram 8'de "Akademik kariyer yapmak istiyorum" ifadesinin oranı \%21 iken, Diyagram 9' da bu oran sadece \%3 oranında gerilemiştir. Diyagram 8 ile 9 karşılaştırıldığında da "çevirmen olarak çalışmak istiyorum” ifadesinin \%10 ve "Çeviri hizmeti verecek bir işletme kurmak istiyorum" ifadesinin \%6 oranında düşmesinin sebeplerini ayrıca araştırmak gerekmektedir. "Başka bir alanda çalışmak istiyorum” cevabının oranında sadece \%1'lik bir farklılık görülmektedir. Bu oranın sabit kalması, Çeviribilim öğrencilerinin bir kısmının kariyer bilinci anlamında istikrarlı bir tutum sergilediğinin göstergesidir.

Diyagram 6 (2015), Diyagram 7 (2019) ile Diyagram 8 (2015), Diyagram 9 (2019) incelendiğinde dengeli cevaplar alabilmek için benzer soruların katılımcılara yöneltildiği görülmektedir. Akademik kariyer isteğinin artmasının olumlu bir gelişme olduğu söylenebilir. Ancak yazılı ve sözlü çeviri yapma isteğinin azalmasının sebeplerini araştırmak gerekmektedir. Nitekim dil endüstrisinin çalışma alanları incelendiğinde reel sektöre yazılı çevirinin hâkim olduğu ifade edilebilir.

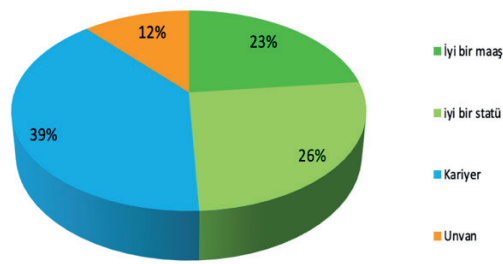

Diyagram 10: (2015)

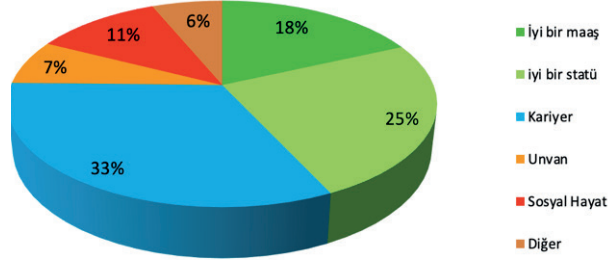

Diyagram 11: (2019) 
Diyagram 10 ve 11 incelendiğinde öğrencilerin “iyi bir statü” isteğinde sadece \%1'lik bir azalma görülmektedir. “Kariyer” isteği oranı 2015'e göre düşmekle beraber yine de yüksek bir seviye göstermektedir.

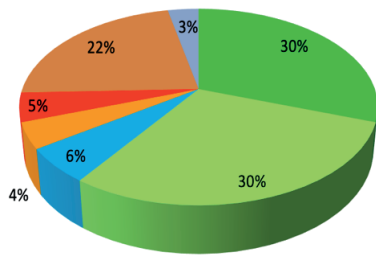

Diyagram 12: (2015)

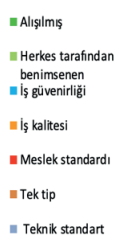

Teknik standart
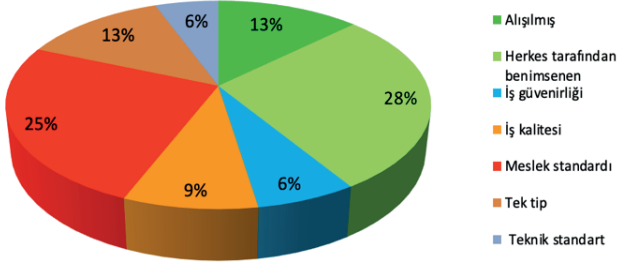

Diyagram 13: (2019)

Çeviribilim bölümü öğrencilerinin "meslek" ve "standart” kavramıyla ilgili bilişsel gelişimlerini tespit etmek amacıyla "Meslek" sizin için ne ifade ediyor?" ve "Standart kavramı sizin için ne ifade ediyor?" soruları 2015 ve 2019'da katılımcılara yöneltilmiştir.

Bu soruların cevapları Diyagram 12 ve 13 'te gösterilmiştir. Diyagram 12 ve 13 'e göre meslek standardının güncelliği ile ilgili yüksek oranda bir geri bildirim sağlanmıştır. Öte yandan "Meslek sizin için ne ifade ediyor" sorusunun cevaplarında bir değişiklik meydana gelmemiştir." Standart” kavramına ilişkin farkındalık düzeyi artış gösterirken, "meslek” kavramına ilişkin farkındalığın yükselmemesi dikkate değerdir.

\section{Sonuç}

Günümüzde dil endüstrisi ciddi bir ekonomik pazar oluşturmaktadır. Dil endüstrisinin gelişmesiyle hem teknolojide hem de eğitimde çeviri, vazgeçilmez bir çalışma alanına dönüşmüştür. Çeviriye yeni teknolojilerin entegre edilmesi çevirmenin iş yükünü kolaylaştırmamıştır. Aksine çevirmenden beklenen yeni niteliklerin çoğalmasına zemin hazırlamıştır. Nitekim çevirmenin bilişsel yeteneğini etkin bir biçimde kullanma zorunluluğu ortaya çıkmaktadır. Çevirmenin daha hızlı ve etkin yanıt vermesi beklentisi, işverenlerin yüksek teknoloji kullanımı talepleri ve rekabet olgusu gibi hususlar çevirinin paydaşlarını olumlu ve olumsuz yönde etkileyebilmektedir. Söz konusu gelişmeler profesyonel tercümanları, çeviri eğitimi almamış alaylı çevirmenleri, çeviri şirketlerini, mütercim tercümanlık öğrencilerini ve öğretim elemanlarını da etkilemiştir (Balkul ve Toptan, 2019). Ancak Proz'un 2012'de uyguladığı anketin sonuçlarına göre teknolojinin dâhil edilme süreci serbest çalışan çevirmenlerin çalışma performansını artırmıştır. Bu doğrultuda Schmitt, Gerstmeyer ve Müller (2016) çevirmenlik mesleği ile ilgili gelişmelere yönelik düzenli anket çalışmaları yapılmasının önemli olduğunu ifade etmektedir. Örneğin FASK'ın (2012) anket sonuçları incelendiğinde de öğrencilerin çevirmenlik mesleğinin geniş iş sahasının farkında olmadıkları için mezuniyetten sonra farklı alanlara yönelme isteği taşıdıkları dikkat çekmektedir. Mevcut araştırmanın anketleri (2015 ve 2019) incelendiğinde de 
çevirmenlik mesleğine olan ilginin azaldığı görülmektedir. Öğrencilerin bölümü kazandıkları yıl çevirmenlik mesleğiyle alakalı farkındalıklarının yüksek olmasına karşın 4 yıllık eğitimin sonunda mesleğe olan ilgi azalmıştır. Sözlü çeviriye karşı ilgi azalırken yazılı çeviri isteğinin oranı da ciddi bir şekilde düşmüştür. Nitekim Budin'in listelediği dil endüstrisi çalışma alanları incelendiğinde çeviri etkinliğine yönelik yeni meslek alanlarının arttığı görülmektedir. Bu doğrultuda öğrencilerle düzenli olarak kapsamlı anket çalışmalarının yapılması mesleğe olan ilginin azalma sebeplerini ortaya koymak açısından önemlidir. Çevirmen olarak çalışma ile bir çeviri işletmesi kurma isteğinin oranında yaşanan düşüşün sebepleri de araştırılmalıdır. Dil endüstrisi kapsamında düzenli toplantılar ve organizasyonlar gerçekleştirildiğinde paydaşlar arasında iletişimi artacak ve işbirliği arttığı sürece kurumlar arasındaki alışverişler ve ortak iş olanakları da büyüyecektir. Öte yandan dil endüstrisinin paydaşları arasında işbirliğinin görünürlüğü sağlandığı sürece, çeviri alanındaki yeni meslek oluşumları da ön plana çıkabilir. Nitekim bölüm tercihinde öğrencilerin çevresinden gelen olumsuz tepkilerin mezuniyet aşamasında da artması çevirmenlik meslek tanıtımının kamuoyu (örneğin, aile, yakın çevre) nezdinde yeterli olmadığını düşündürmektedir. Bu bağlamda çevirmenlik mesleğinin temel görevlerinin toplumsal düzlemde ne kadar bilindiği ayrıca tartışılmalıdır. Çünkü genel anlamda çevirmenin temel görevlerinin toplum tarafından bilinmediğini, yazılı ve görsel medyadan, daha doğrusu televizyondan, haberlerden, internetten ve iş ilanlarından gözlemlemek mümkündür. Başka bir ifadeyle Çeviribilim alanının dil endüstrisinin önemli bir paydaşı olduğuyla ilgili kamuoyunda yeterli düzeyde bir farkındalık bulunmadığı söylenebilir. Ayrıca çevirmenlik mesleği ile ilgili sosyal medyadan bilgi edinme oranının aile ve çevre faktörlerinden gelen bilgilendirme düzeyinden düşük olması, çevirmenlik mesleğinin sosyal medyada yeterince tanıtılmadığına işaret etmektedir. Bu doğrultuda yeni medya araçları üzerinden çevirmenlik mesleğinin çalışma alanlarıyla ilgili bir farkındalık oluşturulabilir. Ayrıca 4 yıllık eğitimin sonunda çevirmen adaylarının akademik kariyer isteğinde ciddi bir yükselişin görülmesi umut vericidir. Bu yükseliş, son dönemdeki ekonomik koşullar dolayısıyla akademisyenliğin bir iş kapısı olarak görülmesi ile izah edilebilir.

Mevcut araştırmanın anket sonuçlarından hareketle çevirmenlik mesleğinin geniş iş yelpazesine yönelik bir farkındalık oluşturulması gerektiği öne sürülebilir. Ancak akademi, bu farkındalığı yaratma noktasında tek başına yeterli değildir. Özellikle Türkiye'de dil endüstrisi, mütercim tercümanlık bölümlerine daha çok entegre edilmeli, işbirliği odaklı projeler ve platformlar geliştirilmelidir. Akademiden tam donamlı çevirmenler yetiştirmesi beklenmektedir. Devlet üniversiteleri, geneli itibariyle teorik açıdan geniş bir bilgi birikimi sağlamasına rağmen uygulama boyutunda aynı başarıyı gösterememektedir. Bu noktada modern teknolojilerle donatılmış ekipmanların bulunmaması örnek gösterilebilir. Bu bağlamda dil endüstrisinin bileşenleri olan Çeviribilim, teknoloji ve eğitim bir sacayağı olarak düşünülmeli, bahsi geçen birimler arasında ortak çalışmalar artırılmalıdır.

Mütercim ve tercümanlık bölümlerinin tanıtım faaliyetleri yoğunlaştırılmalı, çevirmenlik 
mesleğinin geniş bir iş yelpazesinin olduğu kamuoyuna duyurulmalıdır. Çevirmenlik mesleğinin sınırları netlik kazandıkça öğrencilerin bölümü bilinçli bir şekilde tercih etmesi sağlanacak ve ayrıca motivasyonları da artacaktır, bu gelişmeler de dil endüstrisine katkı sunacaktır. Dil endüstrisinin paydaşları arasında görünürlük sağlandığı sürece toplumun talep ettiği dil hizmetlerini yerine getirecek nitelikli elemanların yetiştirilmesi yoluyla ülke ekonomisine katkı sağlanacaktır.

Dil endüstrisinin paydaşları olan “Teknoloji, Çeviribilim ve Eğitim” ortak hareket ettiği takdirde, Türkiye'de çevirmenlik mesleğinin gelişmesine katkı sağlayabilir. Araştırmanın literatür kısmında bahsi geçen ve dil endüstrisine yönelik çalışmalar yürüten şirketlerin faaliyetleri üzerine devlet destekli araştırmaların yapılması dil endüstrisinin mevcut durumunu ortaya koymak açısından önemlidir. IBISWorld Industry ve Common Sense Advisory gibi firmaların düzenli araştırmaları dil endüstrisiyle ilgili güncel veriler sunmaktadır. Pazar araştırması yapan firmaların hazırlamış olduğu raporların yüksek maliyetli telif hakkı nedeniyle kamuoyuyla tam olarak paylaşılmaması, Türkiye'deki dil endüstrisine dair bütüncül bilgilere ulaşılmasını engellemektedir. Bu firmaların raporlarına erişme imkânının sağlanması, dil endüstrisinin dünyadaki nüfuz alanlarıyla ilgili gelişmeleri takip edebilmek ve eksikleri gidermek açısından önem arz etmektedir. Nitekim, Türkiye'de dil endüstrisine yönelik ciddi araştırma raporları bulunmamaktadır. Bu bağlamda 2015 yılında yayımlanan Türkiye'de Çevirmenlik Mesleği Araştırma Raporu dikkate değerdir. Rapora göre "Dünya genelinde çeviri sektörünün maddi boyutu 15 milyar dolar civarındadır. Son yıllarda değişen ve gelişen ilişkiler nedeniyle Türkiye'de çevirmenlik sektörü 5 kata yakın büyümüştür. Bugün çeviri sektörünün (piyasa değerinin) 500 milyon dolarlık kısmı özel sektöre ait olmak üzere $\mathrm{AB}$ müktesebatı ve kamuda gereken çevirilerle birlikte 800 milyon dolara ulaştığı tahmin edilmektedir" (İdare Geliştirme Başkanlığı, 2015).

Günümüzde dil endüstrisinin bir ülkeye ciddi bir kazanç sağladığı aşikârdır. Ancak daha belirgin sayılara ulaşabilmek için güncel çalışmaların yapılması, başka bir deyişle düzenli pazar araştırmalarının yapılması, dil endüstrisi paydaşlarının ortak paydada buluşmasını kolaylaştıracak ve paydaşlar arasında görünür bir işbirliği sağlayacaktır. Sadece pazar araştırmasına yönelik anket çalışmaları değil aynı zamanda çevirmen adaylarının temel beklentilerini öğrenebilmek için mütercim ve tercümanlık bölümünde okuyan öğrencilere yapılacak anket çalışmaları da artırılmalıdır. Özellikle mevcut sorunları tespit etmek, çevirmenlik mesleğinin ileride daha iyi bir statüye kavuşabilmesi için öneriler geliştirebilmek açısından önem arz etmektedir.

Hakem Değerlendirmesi: Dış bağımsız.

Çıkar Çatışması: Yazar çıkar çatışması bildirmemiştir.

Finansal Destek: Yazar bu çalışma için finansal destek almadığını beyan etmiştir.

Peer-review: Externally peer-reviewed.

Conflict of Interest: The author has no conflict of interest to declare.

Grant Support: The author declared that this study has received no financial support. 


\section{KAYNAKÇA/REFERENCES}

Ahmann, H. (2012). Das Trügerische am Berufsbild des Übersetzers. Berlin: Logos Verlag.

Arıkan, R. (2018). Anket Yöntemi üzerine bir Değerlendirme, Haliç Üniversitesi Sosyal Bilimler Dergisi,1, $97,159$.

Balkul H.İ. ve Toptan, D.Ö. (2019). Proz.com Web Sitesi Örnekleminde SanalÇeviri Platformlarındaki İş Akışının Çeviri Eylemi Kuramı ÇerçevesindeDeğerlendirilmesi, International Journal of Languages Education and Teaching 2 (7), 222-235.

Budin, G. (2016). Berufsziel Übersetzen und Dolmetschen M. Kadrić ve K. Kaindl (Ed.), Arbeiten in der Sprachindustrie (s.182-200). Tübingen: A. Francke Verlag.

Dabić, M. (2018). Übersetzen und Dolmetschen: Berufsbilder, Arbeitsfelder, Ausbildung, Ein- und Ausblicke in ein sich wandelndes Berufsfeld der Zukunft, 70 Jahre, L. N. Zybatow ve A. Petrova ve A. Stauder ve M.Ustaszeweski (Ed.) Übersetzen und Dolmetschen Rollenbilder, Arbeitsfelder, Implikationen für den Unterricht (s. 211-228). Innsbrucker Institut für Translationswissenschaft, Peter Lang.

Karakaya, Ş. (1997). Dil, Teknoloji ve Gelecek, Ekev Akademik Dergisi, 1(1), 237-241.

Kurultay, T. (2014). Çok Dilli Kaynaklarda Uluslararası Standartlaştırma Çalışmaları - Uygulamalı Çeviribilimin Gerekliliği Üzerine, Çeviribilim Okumaları, İstanbul Üniversitesi, 103-118.

Özkaya, E. (2010) Avrupa Dil Endüstrisi Derneği İstanbul'daydı. Çeviribilim Online Dergisi. Erişim adresi: https:// ceviribilim.com/author/eozkaya/https://www.academia.edu/23948883/Avrupa_Dil_End\%C3\%BCstrisi_ Derne\%C4\%9Fi_\%C4\%B0stanbuldayd\%C4\%B1 01.05.2021

Öztürk, A. (2017). Modern Dil Teorileri ve Toplumsal Dizayn (Politik Dil Sosyolojisine Giriş), İnsan Ve Toplum Bilimleri Araştırmaları Dergisi 6 (7), 11-31.

Özyeşil, Z. (2011). Öz Anlayış ve Bilinçli Farkındalık, Self Compassion \& Mindfulness, İstanbul: Maya Akademi Yayınları.

Risku, H. (2009). Translationsmanagement, Interkulturelle Fachkommunikation im Informationszeitalter 2. Bask1, Tübingen: Gunter Narr Verlag.

Schmitt, P. A. ve Gerstmeyer, L. ve Müller, S. (Ed.). (2016). Übersetzer und Dolmetscher - Eine Internationale Umfrage zur Berufspraxis, Berlin: BDÜ Fachverlag.

Schopp, F. J. (2012). "Sprachberufe" in Bewegung? Bemerkungen zum Begriff der Proffesionalität und zu aktuellen Entwicklungstendenzen im Translationswesen, Nissilä, N. \& N. Siponkoski (toim.) Kielet liikkeessä, Språk i rörelse, Languages in Motion, Sprachen in Bewegung. VAKKI-symposiumi XXXII 11.12.2.2012. VAKKI Publications 1. Vaasa, 323-334

Şimşek, N. (2014). Farkındalık Bilinci, Ankara: Akçă̆ Yayınları,

Şahin Hisli, N. ve Yeniçeri, Z. (2015). “Farkındalık” Üzerine Üç Araç: Psikolojik Farkındalık, BütünleyiciKendilik Farkındalığı ve Toronto Bilgece Farkındalık Ölçekleri, Türk Psikolojik Dergisi, 30 (76), 48-67

Tokalak Baltacı, F. (2016) Fransızca Mütercim-Tercümanlık Anabilim Dalı̈ Öğrencilerinin Bölümlerine İlişkinTutumlarının Farklı Değişkenler Açısından İncelenmesi, Turkish Studies, 11 (3), 2209-2224

\section{İnternet Kaynakları}

Globalization and Localization Association: GALA Global. Erişim adresi: https://www.gala-global.org/, 01.05 .2021 
Language industry platform: LIND. Erişim adresi: https://ec.europa.eu/info/departments/translation/languageindustry-platform-lind_en, 01.05.2021

Proz.com Freelance translators \& Translation companies ProZ.com. Erişim adresi: https://www.proz. com/01.05.2021

Ölçme, Seçme ve Yerelleştirme Merkezi (ÖSYM). Erişim adresi: https://www.osym.gov.tr/TR,19226/2020yuksekogretim-kurumlari-sinavi-yks-kilavuzu.html 01.05.2021

Transforum, Transport 2050 Erişim adresi: http://www.transforum-project.eu/de/transforum.html 01.05.2021Türkiye'de Çevirmenlik Mesleği Araştırma Raporu, güncellenmiş 2. Versiyon. İdare Geliştirme Başkanlığı. Erişim adresi: https://docplayer.biz.tr/14033160-Turkiye-de-cevirmenlik-meslegi.html, 01.05 .2021 
